\title{
Managing policies for stunting prevention during the COVID- 19 disaster: the case of West Sumatra Province
}

\author{
Azwar $^{I^{*}}$, Muhammad Ichsan Kabullah ${ }^{2,}{ }^{3}$, Lucky Zamzami ${ }^{4}$, and Rifki Dermawan ${ }^{5}$ \\ ${ }^{1}$ Department of Sociology, Faculty of Social and Political Sciences, Andalas University \\ ${ }^{2}$ Department of Public Administration, Faculty of Social and Political Sciences, Andalas University \\ ${ }^{3}$ Centre of Constitutional Studies (PUSaKO), Faculty of Law, Andalas University, \\ ${ }^{4}$ Department of Anthropology, Faculty of Social and Political Sciences, Andalas University \\ ${ }^{5}$ Department of International Relations, Faculty of Social and Political Sciences, Andalas University
}

\begin{abstract}
The Covid-19 pandemic has had major implications for government administration. Policymakers set policies for handling Covid-19 as a priority agenda at this time. However, these measures have reduced other problems such as stunting which still requires government attention. This article explores policy management of stunting by the local government amid the Covid-19 pandemic with the West Sumatra province case. The findings in the field, show that the implementation of stunting prevention policies is not easy considering the powerlessness caused by budget refocusing and overlapping authorities between institutions. Meanwhile, the meaninglessness is indicated by the low level of public support for the handling of stunting. This is exacerbated by a bureaucratic culture that is slow to implement policies, including in managing stunting-related programs during the Covid-19 crisis. So that there is alienation or what we call as alienation in the bureaucracy in implementing stunting prevention policies.In the end, the management of stunting policies during the Covid-19 pandemic should receive strong support from all involved parties.
\end{abstract}

\section{Introduction}

The Covid-19 pandemic has put heavy pressure on all aspects of life. Although the Covid-19 pandemic is classified as a non-natural disaster, the implications it causes are also experienced in government administration where handling Covid-19 has become a policy priority. This is inseparable from the trend of Covid-19 cases, which continues to increase where there are 253,286 people affected by Covid-19 with a death toll of 58,995 people on July 1, 2021 [1]. The government has done its best in handling Covid-19. This is shown through a series of massive regulations and policies. At the central government level, President Joko Widodo has carried out a series of policies such as the establishment of the Task Force for the Acceleration of Handling the Corona Virus through Presidential Decree (Keppres) Number 7 of 2020, which is headed by the Head of the National Disaster Management Agency. The government has also designated Covid-19 as a non-natural national disaster ) [2]. In addition, the government has also implemented lockdown in temporary (PKMM) to contain the spread of Covid-19 cases. In the local government, several regional heads are encouraged to do their best to handle Covid-19, starting from refocusing the budget, increasing social spending, to trimming the regional government's routine budget such as the official travel budget [3].

It should be realized that disasters such as the Covid19 pandemic are situations that will always be faced by the bureaucracy and cannot be avoided considering that no one knows when the Covid-19 pandemic will end. This is termed VUCA (Volatile, Uncertain, Complex, and Ambiguous) a terminology that describes the dynamic, fluctuating, uncertain, complex, and ambiguous multilateral world conditions [4]. It is just that in the discussions that developed, some parties began to realize that an excessive response to Covid-19 could reduce the government's presence in providing guarantees for fulfilling people's welfare in other sectors. Moreover, by looking at the characteristics of the public bureaucracy that has been imaged so far which is full of rigidity, stuck with routines, and procedural, the task of the bureaucracy to accommodate issues other than the Covid-19 pandemic is becoming increasingly difficult [5].

For West Sumatra province itself, one of the problems that have not been resolved by the local government is stunting. Based on the results of the Nutrition Status Monitoring (PSG) in 2015-2017, there was an increase in the prevalence of stunting from $25.5 \%$ in 2016 to $30.6 \%$ in 2017 [6]. In 2018, based on Basic Health Research (Riskesdas) found that the stunting prevalence rate in

\footnotetext{
* Corresponding author: azwar@soc.unand.ac.id
} 
West Sumatra Province increased to $30.8 \%$ [7]. The threeyear trend shows that there has been no progress made by local governments in implementing stunting prevention policies. Indeed, it appears that the numbers stunting prevalence rate in West Sumatra are just equal to the national average of stunting prevalence $30.8 \%$ in 2018 . Therefore, stunting prevention policies must be carried out continuously. All parties, especially policymakers in the government can interpret the stunting issue should receive similar attention with the Covid-19 pandemic.

From the government's point of West Sumatra province, much pressure was put on the bureaucracy in policy implementation of stunting prevention during a pandemic Covid-19. Excessive reporting on Covid-19 has eliminated the problem of stunting as a priority issue in government administration. Even if stunting is to be put forward as a priority agenda by the provincial government, there is a tendency to reject it from the public. This can be seen in the labeling of the Governor of West Sumatra Province as a figure who is considered to have less concern in handling Covid-19 [8]. This indicates that there is great pressure experienced by policymakers if they want to prioritize issues other than Covid-19. Whereas the problem of stunting is acute and has not been completely resolved by the local government. With the enormous pressure faced by policymakers in managing stunting prevention policies, there should be an adaptation in the bureaucracy.

In this article, we would like to identify the factors that hinder the implementation of stunting prevention policies during the Covid-19 disaster. The conceptualization built departs from the theory of policy alienation, which allows us to identify the level of alienation of policymakers in implementing stunting policies during the Covid-19 pandemic. This is theoretically considered relevant considering that the incremental stunting prevention policy is often seen only in a limited way. Even though several other factors create the alienation of stunting policies, which should also be the subject of a thorough analysis by policymakers. In terms of method, the author uses a qualitative method with a case study approach at the West Sumatra Provincial Health Office, by looking in detail at regulatory factors, budgets, and policies

\section{Problem Statement}

What are the factors that hamper the West Sumatra Provincial Government from implementing stunting prevention policies during the Covid-19 disaster?

\section{Research Methods}

To answer the problem statement above, this study will use qualitative methods. The reason for using qualitative methods is the existence of standardized research procedures, thus, they can assist in finding descriptive data both written and oral from the observed phenomena [9]. Qualitative methods are also effective in exploring phenomenon about what is experienced by research subjects such as behavior, perception, motivation, action, and others. For these reasons, qualitative methods are very relevant in identifying the factors that hamper the West Sumatra Provincial Government in implementing stunting prevention policies during the Covid-19 disaster. The data collection was carried out at institutions directly related to stunting prevention policies, including the National Population and Family Planning Agency (BKKBN) of West Sumatra Province, West Sumatra Province Health Office, and West Sumatra Province Social Service. The duration of data collection itself is carried out over a period of two months, from July to August 2021.

\section{Theoretical Framework}

Various policy studies have been conducted in analyzing the problem of stunting in Indonesia. A study from Nisa [10] explains that although stunting prevention is regulated by many regulations, its implementation is not followed by follow-up at the local level to the village level. Another study conducted by Azwar [11] and colleagues describes various social policy packages made by the government as a model for the welfare state that can have an impact on reducing stunting cases. These are the various policies contained in social policy packages such as the Family Hope Program (PKH), Community Health Insurance (Jamkesmas), Smart Indonesia Card (KIP), Home Renovation Assistance Program, and others become part of the indirect intervention in stunting. Tampubolon's [12] also revealed that coordination, funding, and public participation, especially from village government officials, influenced the implementation of stunting prevention policies. Based on these studies, it is clear that stunting prevention policies are still running partially and have not been able to bind many parties.

In this article, we will analyze the factors that hinder the West Sumatra Provincial Government in the implementation of stunting prevention policies using the conceptual framework alienation. The conceptualization of policy alienation departs from the philosophy of a cognitive state faced by implementers who feel alienated from the policy program being implemented [13]. This usually occurs in a complex issue and there is strong pressure from many parties. At the same time, the alienation policy theory is also relevant for policymakers because they can psychologically identify the effectiveness of policy [14]. This is exacerbated by the absence of an accurate database from the local government for people who deserve to receive assistance, a situation that indicates alienation from stakeholders in implementing policies.

In the first variable, powerlessness can be defined as a person's lack of control over the events that are happening in front of them [15]. Seeman [16] defines powerlessness as "the expectation or probability held by the individual that his behavior couldn't determine the outcome of what he has done". In the realm of policy implementation, powerlessness is related to the level of influence that bureaucrats have in shaping policy programs. While the second variable in policy alienation is meaninglessness [17]. Sarros and colleagues [18] define meaninglessness as "the inability to understand the relationship of one's contribution to a larger goal". Further explanation of the 
meaninglessness in policy implementation can be seen from the level of support at the community and client/ customer levels. Through the use of policy alienation as a conceptual framework, this study is expected to provide another perspective in analyzing the implementation of stunting prevention policies.

\section{Results}

\subsection{Overview of Stunting in West Sumatra Province}

The issue of stunting requires great attention for policymakers considering the negative impacts it causes.
According to a study by the Health Research and Development Agency (Balitbangkes) of the Ministry of Health, stunting in other words kerdil or stunted children has real implications for poor educational achievement and low income as adults [19]. Another study conducted by Cahyono and colleagues [20] also revealed that stunting has an impact on reducing the IQ of children in Indonesia by 10 to 15 points, the lack of academic achievement of children and in the long term will exacerbate poverty due to low levels of competence in entering the workforce. Stunting is also likened to a hidden tragedy where the impact does not only affect low intelligence levels but also morbidity and mortality in toddlers, low intellectual and cognitive abilities, and causes degenerative disease problems [21].

Table.1.Statistics of stunted toddlers based on regency/city in West Sumatra province Year 2007 - 2019

\begin{tabular}{|c|c|c|c|c|c|}
\hline No & District/City & $\begin{array}{c}\text { Riskesdas } \\
2007\end{array}$ & $\begin{array}{c}\text { Riskesdas } \\
2013\end{array}$ & $\begin{array}{c}\text { Riskesdas } \\
2018\end{array}$ & SSGBI 2019 \\
\hline 1 & Mentawai Islands & 32.6 & 40.9 & 32.4 & 43.3 \\
\hline 2 & Pesisir Selatan & 37.4 & 50.0 & 26.5 & 30.56 \\
\hline 3 & Kab. Solok & 36.2 & 42.0 & 41.5 & 35.45 \\
\hline 4 & Sijunjung & 46.1 & 37.2 & 35.0 & 30.62 \\
\hline 5 & Tanah Datar & 39.9 & 38.8 & 26.3 & 23.31 \\
\hline 6 & Padang Pariaman & 34.9 & 41.0 & 26.1 & 21.29 \\
\hline 7 & Agam & 36.1 & 30.0 & 30.0 & 26.64 \\
\hline 8 & Limapuluh Kota & 29.8 & 28.8 & 40.1 & 29.94 \\
\hline 9 & Pasaman & 48.6 & 55.2 & 40.6 & 35.67 \\
\hline 10 & Solok Selatan & 34.7 & 48.6 & 27.7 & 34.99 \\
\hline 11 & Dharmasraya & 30.4 & 40.4 & 30.3 & 26.37 \\
\hline 12 & Pasaman Barat & 45.2 & 51.5 & 35.1 & 31.66 \\
\hline 13 & Padang & 30.9 & 33.7 & 22.4 & 20.92 \\
\hline 14 & Solok & 39.4 & 30.7 & 23.6 & 20.73 \\
\hline 15 & Sawahlunto & 31.2 & 22.5 & 20.6 & 23.43 \\
\hline 16 & Padang Panjang & 34.4 & 28.5 & 27.2 & 13.55 \\
\hline 17 & Bukittinggi & 31.0 & 28.5 & 17.2 & 23.46 \\
\hline 18 & Payakumbuh & 44.4 & 30.4 & 19.2 & 22.3 \\
\hline 19 & Pariaman & 23.3 & 44.0 & 17.8 & 20.78 \\
\hline & West Sumatra & 36.5 & 39.2 & 29.9 & 27.47 \\
\hline & National & 36.8 & 37.2 & 30.8 & 27.67 \\
\hline \multicolumn{6}{|c|}{ Categories of Public Health Problems stunting Prevalence according to WHO } \\
\hline \multicolumn{6}{|c|}{ 1. Low (Prevalence $<20 \%$ ) } \\
\hline \multicolumn{6}{|c|}{ 2. Moderate (Prevalence between 20 - 29.9\%) } \\
\hline \multicolumn{6}{|c|}{ 3. High (Prevalence between $30-39.9 \%$ ) } \\
\hline \multicolumn{6}{|c|}{ 4. Very High (Prevalence above $40 \%$ ) } \\
\hline
\end{tabular}


The negative impacts of stunting will be difficult to manage amid the catastrophic pandemic Covid-19 experienced at this time. With the increasing economic burden on families due to the Covid-19 pandemic, it is believed that the poverty experienced by many families can directly affect the increasing malnutrition that children receive. When a child is malnourished, it gradually fails to achieve a normal and healthy height according to the child's age. Therefore, the problem of stunting cannot be intervened locally from a health point of view alone, but as a complex issue that needs to be tackled together.

At the practical level, stunting prevention policies have been carried out across sectors and involve various stakeholders. Stunting prevention efforts implemented by the central government are usually conducted at the macro level with massive scale such as the provision of vitamins and supplementary food, free immunization for toddlers, education about nutrition, and provision of National Health Insurance (JKN), Healthy Indonesia Card (KIS) to the implementation of the Family Hope Program (PKH) [22]. At the local government level, stunting management is carried out through complementary interventions such as optimizing Posyandu in promoting environmental health, reducing poverty, and empowering women [23]. From these various policy interventions, it can be seen that the government in a structured manner starting from the central government and local governments have taken various steps in preventing stunting.

Unfortunately, the stunting problem has not been completely resolved by the government in the West Sumatra Province. This is illustrated by the data on stunting under five in the last thirteen years as shown in table 1

\subsection{Alienation in Stunting Policies}

It is interesting to see the role of local governments in particular the Government of West Sumatra province in implementing prevention policies of stunting. This departs from the reality that the budget capacity of the provincial government is stronger than that of the regencies/municipalities. In addition, with a smaller number of affairs, as stated in Law Number 23 of 2014, the provincial government should be able to fill the resource gap of regencies/ municipalities in the implementation of stunting prevention policies during the Covid-19 disaster. However, this is not easy to realize given the powerlessness and meaninglessness experienced by policymakers.

Powerlessness in policy can be interpreted as the inability of policymakers to control events that occur [24]. In the case of stunting prevention policies in West Sumatra Province, the inability of policymakers in the Provincial Government to accelerate stunting prevention policies is due to budget changes and overlapping authorities between institutions. On the budget side, pandemic Covid-19 has led to changes in budget allocation of every government agencies President Joko Widodo has ordered every provincial government and regencies/municipalities to participate in helping to overcome Covid-19 in their regions, such as by refocusing and reallocating the local budget (APBD), forming regional task forces and increasing social assistance. In the West Sumatra Province case, the provincial government also followed the president's instruction in refocusing and reallocating the budget. Several regulations that require provincial governments to refocus their budgets include Government Regulation in place of Law (Perppu) Number 1 of 2020, Decree of the President of the Republic of Indonesia Number 11 of 2020, Regulation of the Minister of Finance Number 19/PMK.07/2020, Minister of Home Affairs Regulation Ministry of Home Affairs Number 20 of 2020, and Instruction of the Minister of Home Affairs Number 5 of 2020. Through those changes, every government area including West Sumatra Provincial Government needs to do refocusing and re-allocation the budget to support the handling of Covid-19. The provincial government also responded by refocusing the budget for handling Covid19 to reach Rp. 541.2 billion [25]. In other words, as a percentage of the budget, programs/activities for handling Covid-19 received a proportion of $7.3 \%$ of the 2020 West Sumatra Provincial Budget.

In 2021, Provincial Budget still refocusing on the handling of Covid-19 as mandated by the Minister of Home Affairs Regulation Number 64 of 2021. This results in limited budget support for stunting prevention policies. In 2021, the budget allocated West Sumatra Provincial Government for the prevention of stunting only Rp. $148,030,000$. With this budget amount, it is difficult to fulfill the target of reducing the stunting prevalence rate nationally by $14 \%$ in 2024 . The stunting prevalence rate in West Sumatra Province in 2019 still reached 27.47\%, so a $13 \%$ reduction is needed in the next five years.

As for the overlapping authority between institutions, it can be seen from the lack of regulation in determining the main actors who implement stunting prevention policies in West Sumatra Province. At this moment, there is no regional regulation (Perda) at the provincial level that specifically contains the stunting issue. The existence of the Regional Regulation can be a reference for policymakers in implementing stunting prevention policies. The existing regulations related to stunting are the Decree of the Governor of West Sumatra Province Number 440-380-2020 concerning the Establishment of the Team for the Acceleration of Prevention and Handling of stunting in the Province of West Sumatra in 2020, where the Head of the Regional Development Planning Agency (Bappeda) of West Sumatra Province is appointed as the head of the stunting prevention management team. By choosing Bappeda as the leading sector makes no guarantee of the successful implementation of prevention policies stunting in the province of West Sumatra. Bappeda does not have the power of direct execution as owned by other local government organizations such as the health service office and social services office.

The problem of overlapping authority between institutions is also due to the unclear regulations that regulate the authority of institutions. This was explained by one of the informants as follows: 
"... We have a lot of work in this government and not only dealing with Covid. We are also obliged to take care of stunting which is still high... There is still a transition between the health office and the BKKBN, and for the time being there is only a Governor's Decree regarding the acceleration of stunting handling. In the decree, it is stated which OPD is involved in planning stunting activities. " (NS Interview, West Sumatra Provincial Health Office, 22/7/2021)

Based on the interview above shows that BKKBN transition and the health department can not be separated from the discourse of the President in accelerating prevention policy stunting where BKKBN gave a greater role in the management of stunting. The Government of West Sumatra province does not only do the authority of stunting prevention but most of the authority is also taken by the BKKBN. Unfortunately, it was not followed up through more concrete rules. The result is a lack of clarity in the division of responsibility between the provincial governments and the BKKBN so that it can trigger a conflict that has implications for incremental policy.

The meaninglessness can be interpreted as the level of individual understanding of a policy [26]. If the level of individual understanding of a policy is low, it will naturally give birth to resistance in the form of omission and rejection of a policy. Conversely, if the level of individual understanding of a policy is high, support for a policy will appear.

In the context of the stunting prevention policy in West Sumatra Province, meaninglessness is indicated by the low public attention to the stunting issue because it is more diverted to the Covid-19 issue. The Governor of West Sumatra Province, who was considered less responsive in handling Covid-19, as has been reported in the mass media and social media recently, also experienced this. The Governor of West Sumatra Province further stated as follows:

"... We have a lot of work in this government and not only dealing with Covid. We are also obliged to take care of stunting which is still high... There is one area, most of the residents are under $150 \mathrm{~cm}$. In the holiday (Eid alAdha), they have never seen a buffalo. Bringing the buffalo three days and three nights there from Lubuk Sikaping because there is no road access. If through water need three hours. I and my friends from Terabas went to those areas." (Interview with MA, the Governor of West Sumatra province, 29/07/2021)

The statement from the Governor of West Sumatra Province emphasized that the provincial government still have attention in handling stunting during the Covid-19 period. Unfortunately, the attention of policymakers on the stunting issue can be eliminated given the great pressure from the public in the Covid-19 crisis. Concerns arise over the implementation of stunting prevention policies during the Covid-19 situation, forcing every policymaker to be prepared to face resistance that arises from the public when fighting for stunting as an unpopular agenda. Therefore, it is important to build awareness of all parties that the government's task is not only to deal with Covid-19. It takes tactical steps as impartial news and campaigns in the mass media.
The meaninglessness of stunting prevention policies during the Covid-19 pandemic is also influenced by the characteristics of the bureaucracy running very slowly or termed decision-making delays, namely the time lag between the formulation of a policy and its implementation [27]. In the case of stunting, the meaninglessness faced by provincial government policymakers is also due to the inadequacy of government officials to maintain the sustainability of stunting prevention policies. The bureaucracy seems to be run slowly and rigidly, which represents the ongoing Weberian bureaucracy model [28]. At the same time, meaninglessness is indicated by the lack of space for public participation, especially for women. Although the Minang as the biggest ethnic in West Sumatra adheres to a matrilineal system by prioritizing the role of women, the various gender agendas are difficult to implement due to the domination of patriarchy in the bureaucracy [29]. Whereas the position of women in the issue of stunting can be both an object and a subject that can support policy changes. With the participation of women, it can be a force in encouraging the acceleration of the implementation of stunting prevention policies.

\section{Conclusion}

For every policymaker, it is not easy to escape from public pressure if an issue is deemed unpopular. In the context of stunting in West Sumatra, stunting prevention policy stunting is hard to be implemented since the Covid-19 pandemic has become a major issue, and crucial at this time. The alienation of stunting prevention policies is also marked by the powerlessness of the provincial government, especially in terms of budget and interagency coordination and the existence of meaninglessness, especially the minimal support from the wider community. Therefore, the West Sumatra Provincial Government must build a strong will to collaborate with relevant parties to implement stunting prevention policies. In addition, efforts are needed to build a more adaptive bureaucratic management in responding to the stunting problem.

This article is one of the research outputs for the Acceleration of Professorship (PGB) of the Faculty of Social and Political Sciences, Andalas University in 2021. We especially thank all informants for this research. We also express our deepest gratitude to the lecturers and students at the Faculty of Social and Political Sciences, Andalas University who have supported this research. We also give appreciation to reviewers for their constructive input in improving the article. Lastly, we also expressed appreciation to the committee organizing the 2nd International Conference on Disaster Mitigation and Management (ICDMM) who still held the conference during the Covid-19 pandemic.

\section{References}

1. https://www.covid19.go.id/situasi-virus-corona/

2. https://tirto.id/update-corona-indonesia-covid19bencana-nasional-case-reach-117-eFq1 
3. M.I. Kabullah, S. Sudarmoko, H. Koeswara, Rahman, F., \& Azwar, A. Dysfunction of Collaborative Governance in The Handling Policy of Covid-19 at Jambi Province. Jurnal Sosial Humaniora, 14 ,1, 99-111 (2021)

4. E. A. Purwanto, 2019. Agile and Innovative Public Policy in Winning Competition in the VUCA Era (Volatile, Uncertain, Complex and Ambiguous). Inauguration Speech for Professor of Public Policy Gadjah Mada University: Yogyakarta.

5. A. Codreanu, A VUCA Action Framework for A VUCA Environment: Leadership Challenges and Solutions. Journal of Defense Resources Management, 7, 2, 31-38 (2016)

6. M. Syafrina, M. Masrul, \& F. Firdawati, Analysis of the Padang Pariaman Regency Government's Commitment in Overcoming Stunting Problems Based on the Nutrition Commitment Index. Andalas Health Journal, 8 (2), 233-244 (2019)

7. https://www.harianhaluan.com/news/detail/72257/st unting-sumbar-masih-di-atas-20-persen

8. https://langgam.id/dokter-dan-pengamat-kritiksikap-gubernur-sumbar-hadapi-covid-19/

9. W. John, Qualitative Inquiry \& Research Design: Choosing Among Five Approaches. SAGE: Thousand Oaks, California (2013).

10. L. S. Nisa, Stunting Prevention Policy in Indonesia. Journal of Development Policy, 13, 2, 173-179 (2018)

11. A. Azwar., Chatra, E., \& Zuldesni, Z. 2019. Welfare State Policy Model as A Poverty Reduction Strategy in the West Sumatra Districts and Cities. Journal of Anthropology: Socio-Cultural Issues, 21, 2, 227-235

12. D. Tampubolon, Kebijakan Intervensi Penanganan Stunting Terintegrasi. Jurnal Kebijakan Publik, 11. 1, 25-32. (2020)

13. L. G. Tummers, V. J. J. M. Bekkers, \& A. J. Steijn, Policy alienation of public professionals: Application in a new public management context. Public Management Review, 11, 5, 685-706. (2009)

14. M. I. Kabullah, H. Koeswara, \& D. Rahmadi, Alienasi Kebijakan Anggaran Provinsi Riau dalam Pencegahan dan Pengendalian Kebakaran Hutan dan Lahan. Jurnal Administrasi Dan Kebijakan Publik, 5, 2, 114-133. (2020)

15. L. Tummers, Policy Alienation: Analyzing the Experiences of Public Professionals with New Policies. Ph.D. Thesis Erasmus University Rotterdam: Rotterdam. (2012)

16. M. Seeman, On the meaning of alienation. American Sociological Review, 24, 6, 783-791. (1959)
17. L. Tummers, Policy Alienation: Analyzing the Experiences of Public Professionals with New Policies. Ph.D. Thesis Erasmus University Rotterdam: Rotterdam. (2012)

18. J. C. Sarros, G. A. Tanewski, R. P. Winter, J. C. Santora, \& I. L. Densten, Work alienation and organizational leadership. British Journal of Management, 13, 4, 285-304 (2002)

19. T. Trihono, A. Atmarita, D.H. Tjandrarini, A. Irawati, I. Nurlinawati, N. H. Utami, \& T. Tejayanti, Short (stunting) in Indonesia, problems and solutions. Jakarta: Publishing Agency for Research and Development Agency. ( 2015)

20. F. Cahyono, S. P. Manongga, \& I. Picauly, Determinants of stunting in children under five in various ecosystem zones in Kupang Regency. Journal of Nutrition and Food. 11. 1. (2016)

21. N. K. Aryastami, Policy studies and overcoming stunting nutrition problems in Indonesia. Indonesian Bulletin of Health Research, 45, 4, 233-240 (2017)

22. N. F. Rahmawati, N. A. Fajar, \& H. Idris, Social factors, economics, and utilization of posyandu with the incidence of stunting under five of poor families receiving $\mathrm{PKH}$ in Palembang. Indonesian Journal of Clinical Nutrition, 17, 1, 23-33 (2020)

23. L. S. Nisa, Stunting Prevention Policy in Indonesia. Journal of Development Policy, 13, 2, 173-179. (2018)

24. L. Tummers, Policy Alienation: Analyzing the Experiences of Public Professionals with New Policies. Ph.D. Thesis Erasmus University Rotterdam: Rotterdam. (2012)

25. https://dprd.sumbarprov.go.id/home/berita/1/1270

26. L. Tummers, Policy Alienation: Analyzing the Experiences of Public Professionals with New Policies. Ph.D. Thesis Erasmus University Rotterdam: Rotterdam

27. T. Jovanovski, \& M. Muric, The Phenomenon of Lag in Application of the Measures of Monetary Policy. Economic Research-Ekonomska Istraživanja, 24, 2, 154-163. (2012)

28. M. I. Kabullah, The Limits of Weberian on AntiCorruption Approaches in the Indonesian Municipalities. IOP Conference Series: Earth and Environmental Science, 175. (2018)

29. M.I. Kabullah, \& M. N. Fajri, Neo-ibuism in Indonesian politics: election campaigns of wives of regional heads in West Sumatra in 2019 Journal of Current Southeast Asian Affairs 40 (1): 136-155. (2021) 